\title{
STATUS OF HbA1c;
}

Iron deficient diabetic and non diabetic patients.

Miss Nudrat Anwar Zuberi, Mr. Naveed Ahsan, Miss Aliya Jafri, Miss Tehseen Iqbal, Miss Tahira Parveen

ABSTRACT... Background: Glycated hemoglobin [HbA1c] is a marker to identify the average plasma glucose level over past three months but it is also influenced by the iron deficiency status of an individual. Objective: Research is designed to assess the relationship between HbA1c concentration and iron status among diabetic and non diabetic subjects. Design: Cross sectional comparative study. Setting: Tertiary Care Unit of Karachi, Pakistan. Period: Dec 2010 till June 2011. Material and methods: A total of 75 subjects of both sexes were taken and divided into three groups. Fasting and random glucose levels, serum iron and TIBC were performed by enzymatic method while HbA1c was estimated by fast iron resin separation method and Complete blood count (CBC) was done by Coulter. Statistical analysis: The data feeding and analysis was on computer package SPSS (Statistical Packages of Social Sciences) version 16.0. the results were given in the mean and Standard Deviation (SD) and correlation ( $r$ ) for quantitative data i.e. age, FBS, RBS, HbA1c, Serum Iron, Hb HCT, and TIBC. Using Analysis of Variance (ANOVA) with tukey test for comparison (Controls, Iron deficiency anemia with and without diabetes mellitus). In all statistical analysis only $p<0.01$ will be considered significant. Results: HbA1c is a non-specific marker of Diabetes mellitus in iron deficieny anemia patients. Thus it is reccomended that iron status of diabetic patients must be considered while interpreting results. This study showed significantly raised levels of Fasting blood glucose (FBS), random blood glucose (RBS) and HbA1c in diabetic anemic patients when compared to control and nondiabetic anemic subjects $(p<0.01)$ while total iron binding capacity (TIBC) and $\mathrm{HbA1c}$ in nondiabetic anemic subjects were also significantly raised when compared to control ( $p<0.01)$. Hemoglobin $(\mathrm{Hb})$, Hematocrit (HCT) and Serum Iron levels were significantly decreased in diabetic and nondiabetic anemic subjects when compared to control $(p<0.01)$. Conclusions: Our study depicted that while diagnosing Diabetes mellitus in iron deficient patients one should be carefull as HbA1c is not a very reliable parameter to assess glycemic control in iron deficiency anemia patients.

Key words: Diabetes mellitus, HbA1c, Iron deficiency anemia.

\section{Article Citation}

$\checkmark \quad$ Zuberi NA, Ahsan N, Jafri A, lqbal T, Parveen T. Status of HbA1c in iron deficient diabetic and non diabetic patients. Professional Med J Feb 2013;20(1): 054-059.

\section{INTRODUCTION}

Diabetes Mellitus is a chronic metabolic disorder affecting around 200 million people worldwide and is responsible for 32 million deaths in a year ${ }^{1}$ and by year 2030 its prevalence will be increased to $4.4 \%{ }^{2}$. In Pakistan it's prevalence is $10 \%$ of adult population ${ }^{3}$.

Diabetes mellitus is of two types, Type 1 also called insulin dependent diabetes mellitus [IDDM] and type 2 also called non-insulin dependent diabetes mellitus [NIDDM]. Type 2 diabetes mellitus is a heterogeneous multifactorial disorder resulting from either insulin resistance or abnormalities of insulin receptor. It usually develops after the age of 40 but can be seen in thirties in obese people ${ }^{4}$. The current WHO diagnostic criteria for diabetes is maintained as fasting plasma glucose $\geqslant 7.0 \mathrm{mmol} / \mathrm{l}(126 \mathrm{mg} / \mathrm{dl})$ of $2-\mathrm{h}$ plasma glucose $\geqslant 11.1 \mathrm{mmol} / /(200 \mathrm{mg} / \mathrm{dl})^{5}$. In $1976 \mathrm{HbA1c}$ was first time used to assess the level of glucose in diabetic patients ${ }^{6}$. Glycated hemoglobin [HbA1C] is one of the well established method to identify the average plasma glucose level over last 120 days or 3 months of time in patient with diabetes ${ }^{7}$.

Iron deficiency is one of the most common nutritional deficiencies $^{8}$. HbA1C is influenced by conditions that effect erythrocyte survival as well as blood glucose level ${ }^{9}$. Any condition that shortens the lifespan of RBC, such as hereditary spherocytosis, hemolysis, sickle cell anemia, thalessemias, acute blood loss or chronic blood loss will shorten the time of exposure of the hemoglobin protein to circulating glucose and 
decrease the glycosylation process ${ }^{10}$. HbA1c is found to be raised in iron deficiency anemia patient ${ }^{11}$. The relationship between iron deficiency anemia and concentration of $\mathrm{HbA} 1 \mathrm{c}$ has received limited attention.

\section{MATERIAL AND METHODS}

This cross sectional comparative study was carried out in a tertiary care unit during a time period of December 2010 till June 2011. A total 75 subjects of both sexes were included in our study which were divided into three groups $A, B, C$. The first group $A$ includes normal healthy subjects as control. The second group $B$ includes patients of iron deficiency anemia but non diabetic. The third group $C$ includes patients of iron deficiency anemia having diabetes mellitus.

\section{INCLUSION CRITERIA}

Diagnosed and uncomplicated patients of diabetes mellitus with and without iron deficiency anemia.

\section{EXCLUSION CRITERIA}

Patients with a history of acute blood loss and blood transfusion within last six months, taking any iron therapy, hemolytic anemia, vitamin B12 deficiency, hemoglobinopathy, pregnancy and chronic kidney and liver disease were excluded from this study.

\section{SAMPLE COLLECTION AND STORAGE}

A written consent was taken from all study subjects. There was no difference of age and sex and randomized samples were collected. History and physical examination was performed. About $7 \mathrm{ml}$ of fasting and random venous blood was collected from all study subjects using disposable syringes under all aseptic measures and was transferred to a centrifuge tube and allowed to clot for 5-10 minutes at a speed of 2500-3000rpm. The serum obtained was transferred to clean, dry plastic cups. The cups were properly covered, labeled and stored at $-50^{\circ} \mathrm{C}$ till analyzed. Before analyzing serum was thawed and allowed to attain room temperature. EDTA was used as anticoagulant. Following biochemical and hematological parameter were performed. Fasting and Random glucose level, HbA1c, Hemoglobin $(\mathrm{Hb})$, Hematocrit (HCT), Serum Iron and TIBC.

Fasting and Random glucose was estimated by GODPAP method. Serum Iron and TIBC were done by enzymatic kit method. Glycated $\mathrm{HbA} 1 \mathrm{C}$ was estimated by fast ion exchange resin separation method,. Hemoglobin and HCT were measured by coultor.

\section{RESULTS}

Table I shows a comparison of age, FBS, RBS and hematological parameters in control, non diabetic iron deficient and diabetic iron deficient patients.

A total of 75 subjects were taken in this study and were divided into three groups. Group A has 25 controls with mean age of $35.48 \pm 13.11$, group $B$ includes 25 subjects with mean age of $49.56 \pm 12.99$ having iron deficiency anemia but were non diabetic and group $\mathrm{C}$ include 25 subjects with mean age of $40.16 \pm 10.66$ having diabetes as well as iron deficiency anemia.

FBS, RBS, TIBC and HbA1c levels were significantly high as compared to control and nondiabetic iron deficient patients with a $p<0.01$.

$\mathrm{HbA1C}$ and TIBC levels were found to significantly high in nondiabetic iron deficient patients when compared with control with a $p<0.01$.

$\mathrm{Hb}, \mathrm{HCT} / \mathrm{PCV}$ and serum iron levels were significant when compared to non diabetic iron deficient and diabetic iron deficient subjects with $p<0.01$. Serum iron was significantly high when compared with non diabetic iron deficient subjects $p<0.01$.

Table Il shows Pearson correlation of $\mathrm{HbA1c}$ with age and biochemical parameters.

FBS show a significant negative correlation in group $B$ 
( nondiabetic with iron deficiency anemia) $p<0.05$. RBS showed a positive correlation with $\mathrm{HbA1C}$ in group A ( control) and group C ( diabetic with iron deficiency anemia). Hb concentration and HCT / PCV showed a negative correlation in group $C$. Serum iron had a negative correlation in group $B$ and group $C p<$
0.05 .

\section{DISCUSSION}

Diabetes mellitus is a global problem that affects about 200 million people around the world responsible for 32 million deaths per year'. Glycated hemoglobin is one of

\begin{tabular}{|c|c|c|c|c|}
\hline Variables & $\begin{array}{l}\text { Controls } \\
(n=25) \\
\text { Mean } \pm \text { S.D }\end{array}$ & $\begin{array}{l}\text { Non diabetic with iron deficiency } \\
\qquad(n=25) \\
\text { Mean } \pm \text { S.D }\end{array}$ & $\begin{array}{c}\text { Diabetic with iron deficiency } \\
(n=25) \\
\text { Mean } \pm \text { S.D }\end{array}$ & P-value \\
\hline Age in years & $38.48 \pm 13.11$ & $49.56 \pm 12.99$ & $40.16 \pm 10.66$ & 0.001 \\
\hline FBS & $82.24 \pm 9.61$ & $81.76 \pm 8.49$ & $142.36 \pm 39.66$ 潾 & 0.001 \\
\hline RBS & $152.52 \pm 19.34$ & $149.92 \pm 31.18$ & $202.32 \pm 30.07$ & 0.001 \\
\hline $\mathrm{HbA1c}$ & $6.92 \pm 0.54$ & $9.36 \pm 2.04^{+}$ & $10.94 \pm 1.23$ * & 0.001 \\
\hline $\mathrm{Hb}(\mathrm{gm} / \mathrm{dl})$ & $12.16 \pm 1.30$ & $10.29 \pm 2.01$ & $10.86 \pm 1.76$ & 0.001 \\
\hline $\mathrm{HCT} / \mathrm{PCV}$ & $37.88 \pm 3.84 \square$ & $32.35 \pm 5.93$ & $34.04 \pm 5.20$ & 0.001 \\
\hline Serum Iron & $99.00 \pm 15.76$ " & $48.08 \pm 12.26$ & $67.36 \pm 26.02 \bigcirc$ & 0.001 \\
\hline TIBC & $306.40 \pm 27.44$ & $371.75 \pm 65.70^{+}$ & $416.08 \pm 37.33$ 萧 & 0.001 \\
\hline \multicolumn{5}{|c|}{$\begin{array}{l}\text { Significantly high as compared to controls and non-diabetic } p<0.01 \\
\quad+\text { Significant as compared to controls } p<0.01 \\
\text { icantly high as compared to non-diabetic and diabetic with iron deficiency } p<0.01 \\
\text { Significantly high as compared to non-diabetic with iron deficiency } p<0.01\end{array}$} \\
\hline
\end{tabular}
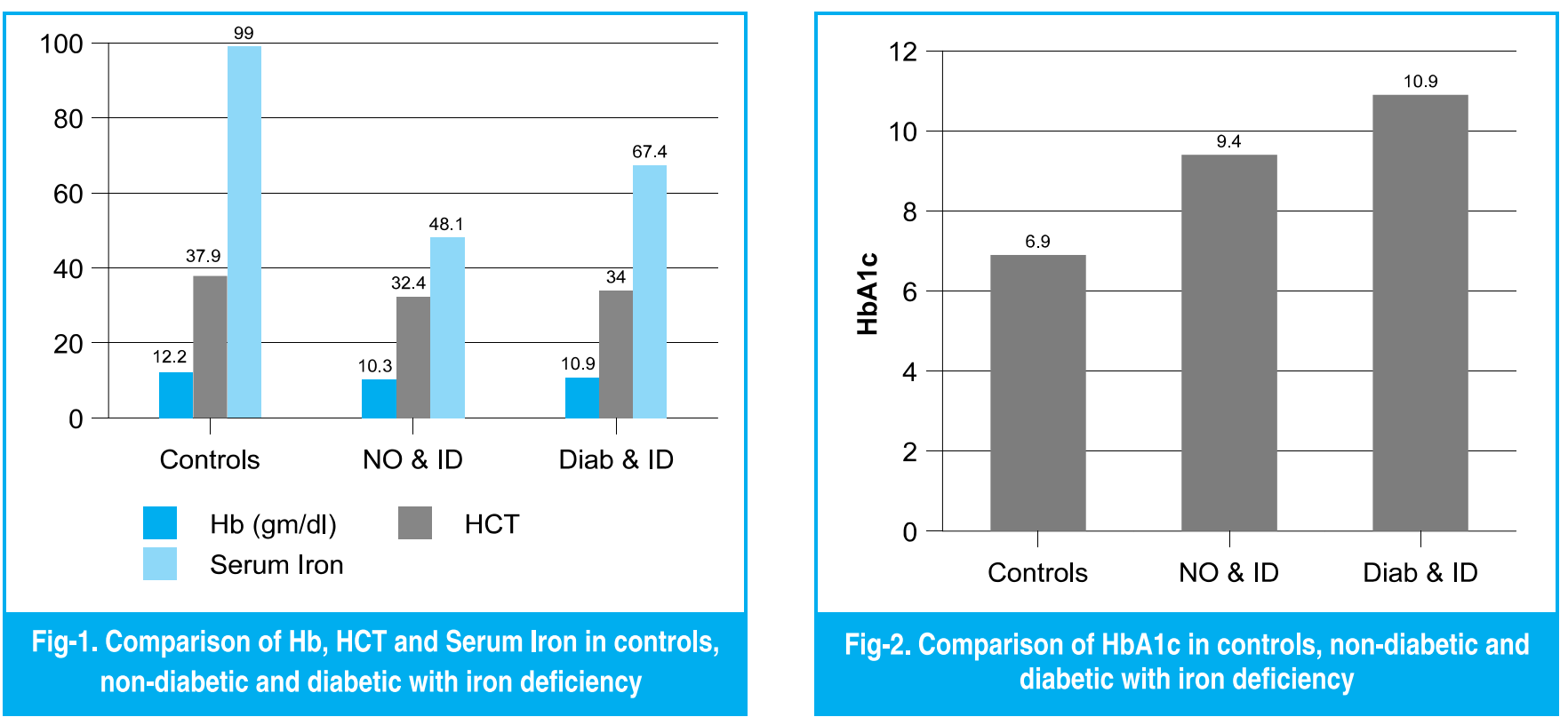


\begin{tabular}{|l|c|c|c|}
\hline $\begin{array}{l}\text { Correlation } \\
\text { of HbA1c }\end{array}$ & $\begin{array}{c}\text { Controls } \\
(\mathbf{n}=25)\end{array}$ & $\begin{array}{c}\text { Non diabetic } \\
\text { with iron } \\
\text { deficiency } \\
(\mathbf{n}=25)\end{array}$ & $\begin{array}{c}\text { Diabetic with } \\
\text { iron } \\
\text { deficiency } \\
(\mathbf{n}=25)\end{array}$ \\
\hline Age in years & $r=-0.18$ & $r=-0.35$ & $r=0.15$ \\
\hline FBS & $r=0.11$ & $r=-0.45^{*}$ & $r=0.17$ \\
\hline RBS & $r=0.91$ & $r=0.07$ & $r=0.46^{*}$ \\
\hline Hb. (mg/dl) & $r=0.03$ & $r=0.38$ & $r=-0.51^{*}$ \\
\hline HCT/PCV & $r=0.03$ & $r=0.38$ & $r=-0.51^{*}$ \\
\hline Serum Iron & $r=0.19$ & $r=-0.43^{*}$ & $r=-0.69^{*}$ \\
\hline TIBC & $r=0.23$ & $r=0.17$ & $r=-0.15$ \\
\hline $\begin{array}{l}\text { *Significant correlation } \\
\text { P < 0.05 }\end{array}$ & & \\
\hline
\end{tabular}

the well-established method by which average blood plasma glucose level can be assessed over the past 120 days or three months. Iron deficiency anemia is one of the most common nutritional deficiencies in Southeast Asia and especially in Pakistan mostly affecting the females. This study was designed to evaluate the status of $\mathrm{HbA} 1 \mathrm{c}$ in relation to iron deficient diabetic and non-diabetic patients. Besides blood sugar there are other conditions that can falsely increase the level of $\mathrm{HbA} 1 \mathrm{c}$. These Conditions include Hereditary Spherocytosis, Hemolysis, Sickle-Cell Anemia, Thalassemia, Acute or Chronic Blood Loss, Iron Deficiency Anemia, Vitamin B-12 Anemia, Folate Deficiency Anemia and Patients with Chronic Kidney Disease $^{10}$.

This study showed significant raised level of $\mathrm{HbA} 1 \mathrm{c}$ in diabetic anemic patients when compared to control and non-diabetic anemic subjects. These Finding matched with Brooks et al ${ }^{12}$ who assessed $\mathrm{HbA} 1$ in 35 non-diabetic patients with iron-deficiency anemia and observed that $\mathrm{HbA} 1$ levels were significantly high in iron-deficiency anemia patients. Our study also found that $\mathrm{HbA1c}$ was also significantly high in non-diabetic anemic patients which matches with El-Agouza et al ${ }^{13}$ who observed that $\mathrm{HbA1c}$ concentration were found to be higher in iron-deficiency anemia patients and decreased when they were given iron therapy. These finding also matched with Nitin Sinha et $\mathrm{al}^{10}$ who observed that HbA1c level were significantly low in iron deficiency anemic patients and its level was increased when iron therapy was given.

Sluiter et $\mathrm{al}^{14}$ suggested that formation of Glycated Hemoglobin is an irreversible process so the concentrations of $\mathrm{HbA} 1$ in $\mathrm{RBC}$ increased linearly with the age of the cell. However if iron deficiency is of long duration the level of red cell formation would fall leading not only to anemia also increased age of circulating red blood cell and increased $\mathrm{HbA} 1$ level. His Study matches with our result which showed that $\mathrm{HbA1c}$ is not only raised in iron deficient diabetic patients but also found to be high in non-diabetic anemic patients. Rai KB et $\mathrm{al}^{15}$ conducted a study in India on 15 non-diabetic subjects having irondeficiency anemia and failed to find a difference in mean concentration of $\mathrm{HbA1c}$. Hansen et al16 also observed that there was no significant difference in $\mathrm{HbA1C}$ concentration in iron-deficient patients, Vitamin B-12 deficient patients and healthy controls. These Studies contradicts with our results.

\section{CONCLUSIONS}

Thus we conclude that $\mathrm{HbA} 1 \mathrm{c}$ should not be used as a reliable marker in patient's having iron-deficiency anemia whether they are diabetic or non-diabetic. Further research is needed on larger scale with role of other factors like inflammation affecting $\mathrm{HbA} 1 \mathrm{c}$ levels.

\section{Copyright@ 14 Nov, 2012.}

\section{REFERENCES}

1. International Diabetes Federation Press release Karachi, Pakistan-26 February 2006 - Diabetes kills without distinction. (Online) 2009 (Cited 2007 June 15).Available from URL: http://www.idf.org/ home/index.cfm?unode=DE93DC2D- 468B-4C7591DA-69314504BD0E. 
2. Chandrashekar M S, Deepa K, Kumar VS Comprehensive review on HbA1c in diagnosis of diabetes mellitus. International Journal of Pharmaceutical Sciences Review and research 2010; 3(2):119-22 .

3. Shera AS, Rafique G, Khuwaja IA. Pakistan National Diabetes Survey. Prevalence of glucose intolerance and associated factors in North Wet Frontier Province (NWFP) of Pakistan. J Pak Med Assoc 1999; 49(9):206-11.

4. Powers A C. Diabetes Mellitus. In: Jameson JL. (editor) Harrison's Endocrinology. 1st ed. New York: McGraw-Hill; 2006. p 303-4.

5

whqlibdoc.who.int/publications/2006/9241594934_e ng.pdf)

6. Koenig RJ, Peterson CM, Jones RL, Saudek C, Lehrman $\mathrm{M}$, Cerami A. Correlation of glucose regulation and hemoglobinAlc in diabetes mellitus. N. Engl. J. Med. 1976 ;295 (8): 417-20.

7. Goldstein DE, Little RR, Lorenz RA, Malone JI, Nathan D, Peterson CM, Sacks DB. Tests of glycemia in diabetes. Diabetes Care 2004;27:1761-1773.

8. Looker A, Dallman P, Carroll M, Gunter E, Johnson C. Prevalence of iron deficiency in the United States. JAMA 277:973-976,1997.

9. Fitzgibbons JF, Koler RD, Jones RT. Red cell age- related changes of hemoglobins Ala $+b$ and Alc in normal and diabetic subjects. J Clin Invest 1976;58:820-824.

10. Nitin Sinha, M.D., T.K. Mishra, M.D. Tejinder Singh, M.D., and Naresh Gupta, M.D. Effect of Iron Deficiency Anemia on Hemoglobin A1c Levels. Ann Lab Med 2012;32:17-22.

11. Coban E, Ozdogan M, Timuragaoglu A. Effect of iron deficiency anemia on the levels of hemoglobin A1c in nondiabetic patients. Acta Haematol 2004;112:126 128.

12. Brooks AP, Metcalfe J, Day JL, Edwards MS. Iron deficiency and glycosylated haemoglobin $\mathrm{A}$. Lancet 1980;2:141.

13. El-Agouza I, Abu Shohla A, Sirdah M. The effect of iron deficiency anaemia on the levels of haemoglobin subtypes: possible consequences for clinical diagnosis. Clin Lab Haematol 2002;24:285-9.

14. Sluiter WJ, Van Essen LH, Reitsma WD, Doorenbos H. Glycosylated haemoglobin and iron deficiency. Lancet 1980;2:531-2.

15. Rai KB and Pattabiraman TN. Glycosylated haemoglobin levels in iron deficiency anaemia. Indian J Med Res 1986;83:234-6.

16. Gram-Hansen P, Eriksen J, Mourits-Andersen T, Olesen L. Glycosylated haemoglobin (HbA1c) in iron- and vitamin B12 deficiency. J Intern Med 1990;227:133-6.

\section{AUTHOR(S):}

1. MISS NUDRAT ANWAR ZUBERI

2. MR. NAVEED AHSAN

3. MISS ALIYA JAFRI

4. Miss Tehseen Iqbal

5. Miss Tahira Parveen

Department of Biochemistry, University of Karachi
CORRESPONDENCE ADDRESS:

Miss Nudrat Anwar Zuberi

Department of Biochemistry, BMSI, JPMC.

nudrat_zuberi@yahoo.com 


\section{PREVIOUS RELATED STUDIES}

KM Yahya, Khalid lqbal, Huma Yahya. HBA1C; STATUS OF DIABETIC CONTROL IN URBAN FAISALABAD (Original) Prof Med Jour 18(3) 430-435 Jul, Aug, Sep 2011.

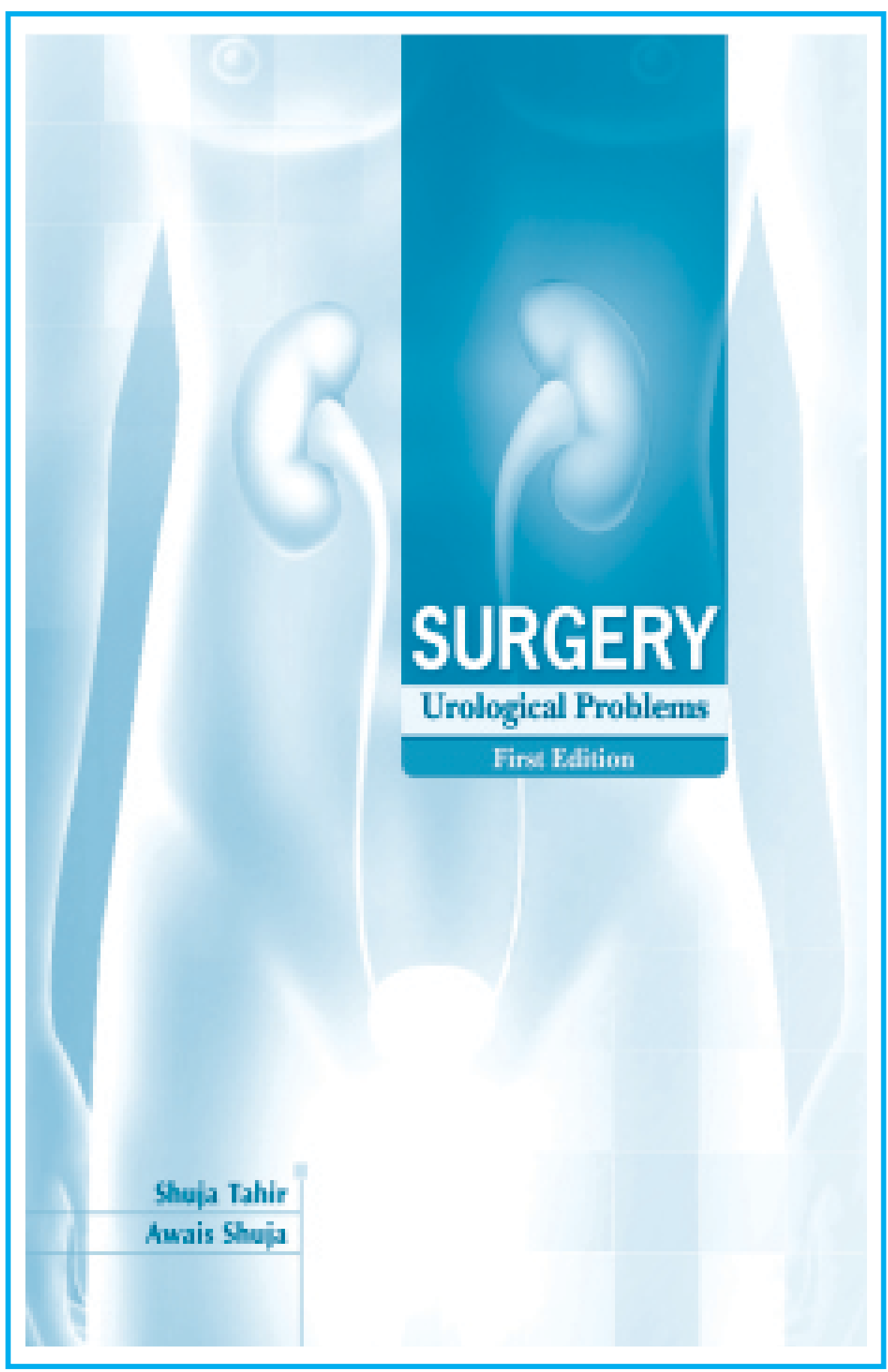

